\title{
Users' Perceptions of Various Aspects of Malaysian Internet Financial Reporting
}

\author{
Mohd Noor Azli Ali Khan ${ }^{1}$ and Noor Azizi Ismail ${ }^{2}$ \\ ${ }^{1}$ Faculty of Management and Human Resource Development, Universiti Teknologi Malaysia, \\ Johor, Malaysia \\ ${ }^{2}$ College of Business, Universiti Utara Malaysia, Kedah, Malaysia
}

\begin{abstract}
The present study seeks to empirically investigate the perceptions of users of corporate annual report on the various aspects of internet financial reporting (IFR). Further, this paper examines the factors that influence companies in Malaysia to engage in IFR. Finally, perceptions of advantages and problems in using this new technology for financial reporting were also examined. The perceptions of users of corporate annual report were solicited using a survey mailed questionnaire of four different user-groups. The findings of this study suggested three main benefits to companies that engage in IFR: attracting foreign investors, promoting company wider to the public, and providing wider coverage. The findings also revealed that three main benefits to the users who collect financial information of companies via their website are: increasing timeliness and efficiency in obtaining financial information, making investment decision process easier and faster, and providing information for company inexpensively. The outcome of the analysis revealed that three factors that are perceived as important by responding firms to engage in IFR: enhancing corporate image, company teller with the technology development, and competitors in the industry. The findings also suggested three factors that inhibit firms from engaging in IFR: The required expertise from the company, the need to keep information updated to be of use, and the concern over security of information. Another important result revealed the increased information and analysis as the most important advantages from financial reporting on the Internet. Moreover, security problems are the disadvantages of placing financial information on the Internet. The evidence on Malaysia is relevant to other emerging capital markets. Finally, the implication of research findings and future research will also be discussed.
\end{abstract}

Keywords: Users, benefit, factor, advantage, disadvantage, Internet financial reporting (IFR).

\section{Introduction}

The adoption of the internet as a global practice for dissemination of financial information is common for an increasing number of publicly listed firms around the world (Moradi et al., 2011; Boubaker et al., 2012). While Internet financial reporting (hereinafter referred to as IFR) is fast becoming the norm in most developed countries, there is little empirical evidence of the phenomenon in the emerging markets region. Internet is a very exciting medium to look into especially with regards to presentation, disclosure and financial reporting (Ali Khan \& Ismail, 2012). The

Copyright (C) 2012 Mohd Noor Azli Ali Khan and Noor Azizi Ismail. This is an open access article distributed under the Creative Commons Attribution License unported 3.0, which permits unrestricted use, distribution, and reproduction in any medium, provided that original work is properly cited. Contact author: Mohd Noor Azli Ali Khan E-mail: m-nazli@utm.my 
Internet is a technology with the power to revolutionize external reporting and is increasingly important for financial reporting (Jones \& Xiao, 2004). The Internet also provides a unique form of corporate voluntary disclosure that enables companies to provide information instantaneously to global audience (Abdelsalam et al., 2007). Internet communication is multidirectional in nature and very fast in transmission (Sanchez et al., 2011). The development of the Internet as a distribution channel of financial information creates a new communication medium and reporting environment in the corporate world (Ashbaugh et al., 1999; Chan \& Wickramasinghe, 2006). The practice of disseminating business information in a digital format is spreading around the world (Bonson et al., 2006), and becoming a very important part of business information services (Liu, 2000). Corporations have the ability to deliver unfiltered information to their publics without a time lag (Sanchez et al., 2011). It is a unique information disclosure tool that encourages flexible forms of presentation and allows immediate, broad, and inexpensive communication to investors (Kelton \& Yang, 2008).

A comprehensive review of existing literature on IFR indicates a significant evolution of IFR research. The evolution of IFR research can be categorized into several themes; classification of IFR, descriptive studies, association studies and dimension of IFR (Ali Khan \& Ismail, 2008a; Ali Khan \& Ismail, 2012). The research on IFR also can be divided into three main categories: descriptive research by one or more countries, research by professional bodies and explanatory research (Ali Khan, 2010). An extensive literature and a number of theories exist to explain the traditional voluntary disclosure such as agency theory, signaling theory, capital market theory and cost-benefit analysis (Desoky, 20098). Otherwise, there are three theories (agency theory, signaling theory and innovation diffusion) that have been employed to explain why a company may voluntarily disclose information in the internet (Nurunnabi \& Hossain, 2012). The review of IFR studies can be classified into the first and second generation (Al-Htaybat, 2011). The literature of IFR falls into three types of categories: descriptive, comparative and explanatory (Boubaker et al., 2012). Even though there are a lot of researches carried out with regard to IFR including those in developing countries like Malaysia, the understanding on the various aspects of IFR is still blurring. While researchers have given considerable attentions to IFR research over the last decade, only a limited number of studies have emerged to explain the relationship between corporate behavior, attitudes and preferences of users of corporate annual report, especially in the context of emerging economies like Malaysia. Therefore, this study is the first attempt to explore in depth users of corporate annual report about their perceptions of the benefits, factors, advantages and disadvantages of IFR.

The remaining sections of this paper are organised as follows. The next section provides an overview of IFR. Section three discusses the research design, followed by research findings. The paper ends with a conclusion and suggestions for future research.

\section{Prior Studies}

There have been a growing number of empirical studies on IFR since 1995 reflecting the growth in this form of information dissemination (Davey \& Homkajohn, 2004). Recently, there has been a dramatic increase in the use of internet to disseminate corporate information (Boubaker et al., 2012). The IFR is a modern technology which has been introduced in the area of financial reporting (Moradi et al., 2011). IFR is more cost effective, faster, flexible in format, and accessible to all types of users nationally and globally (Debreceny et al., 2002). IFR is also an attractive and fast growing research topic (Oyelere et al., 2003; Xiao et al., 2005). A lot of IFR researches have 
emerged over the last decade. The earliest studies were produced during 1996 and 1997, only a year after the global, corporate interest in the Internet as the advertising media had commenced (Allam \& Lymer, 2003).

In general, the IFR literature can be classified into several themes: descriptive research, comparative research and explanatory research (Pervan, 2006; Abdelsalam et al., 2007). The research on web reporting can be divided into two main categories; descriptive research and explanatory research (Marston \& Polei, 2004; Al-Moghaiwli, 2009; Desoky, 2009; Garg \& Verma, 2010). Furthermore, the trend of IFR researches starts from descriptive research, comparative research, association research, dimension and timeliness of IFR (Ali Khan \& Ismail, 2012). Previous studies in IFR area are classified into four groups: descriptive studies, comparative studies, analytical studies, and recommendations of regulators (Henchiri, 2011). In addition, IFR research can be classified into first generation, which was mainly a descriptive survey assessing company Internet practices. Then, second generations to measure the level of financial disclosure in company websites by using a disclosure index and examined factor (AlHtaybat, 2011).

The advantages of the Internet for financial reporting are its cheapness, speed, dynamism, and flexibility (Lymer, 1999). Corporate websites are designed for multiple reasons, including advertising the firms' products, facilitating electronic commerce, promoting brand identification, attracting potential employees, and enhancing the corporate image (Lybaert, 2002). IFR can be cost effective, fast, flexible in format, and accessible to all users within and beyond national boundaries (Haniffa \& Ab. Rashid, 2004). Indeed, IFR is one of the fast growing phenomenons (Ashbaugh et al., 1999; Oyelere et al., 2003). The development of IFR practice has been rapid, largely mirroring, and motivated by, the development of the World Wide Web (WWW) since 1994, being the primary Internet medium for IFR (Allam \& Lymer, 2003). Several professional studies in the US, UK and Canada have also examined the status of IFR. These include the Institute of Chartered Accountants in England and Wales (ICAEW) (Spaul, 1997), the International Accounting Standard Committee (IASC), now the International Accounting Standards Board (IASB) (Lymer et al., 1999), Canadian Institute of Chartered Accountants (CICA) (Trites, 1999), and the U.S. Financial Accounting Standards Board (FASB) (FASB 2000, 2001).

IFR practices have been surveyed by a number of academic studies in many countries, for example US (Petravick \& Gillett, 1996; Ashbaugh et al., 1999; Ettredge et al., 2001; Hindi \& Rich, 2010), UK (Lymer, 1997; Marston \& Leow, 1998; Craven \& Marston, 1999), Japan (Marston, 2003), New Zealand (McDonald \& Lont, 2001; Oyelere et al., 2003) and Ireland (Brennan \& Hourigan, 1998). Several studies have also examined the relationship between firm specific characteristics and IFR (see, for example, Ashbaugh et al., 1999; Craven \& Marston, 1999; Hassan et al., 1999; Pirchegger \& Wagenhofer, 1999; Bonson \& Escobar, 2002; Debreceny et al., 2002; Allam \& Lymer, 2003; Joshi \& Al-Modhahki, 2003; Oyelere et al., 2003; Marston \& Polei, 2004; Xiao et al., 2004; Chan \& Wickramasinghe, 2006; Ali Khan, 2010; Aly et al., 2010; Al-Htaybat, 2011; Pervan \& Sabljic, 2011; Sanchez et al., 2011). These studies have provided evidence on the factors motivating the IFR behaviour of companies around the world.

While numerous studies have examined the status and determinants of IFR, only few studies have focused on the timeliness issue which is an important part of IFR (Pirchegger \& Wagenhofer, 1999; Ettredge et al., 2002; Abdelsalam \& Street, 2007). Timeliness is crucial as users are demanding for more timely information (Fisher et al., 2004). It is even more important as shorter delays are often associated with greater profitability (reference). Unfortunately, many companies are found to focus more on the user support 
and information content than timeliness and technology (Davey and Homkajohn, 2004).

Studies on the perceptions of IFR from the users' and preparers' perspectives are very limited compared to those of traditional reporting. Three exceptions is a study by Joshi and Al-Modhahki (2003). They found 'global reach and mass communication', 'timeliness and updateability' and 'interaction and feedback' as important advantages of IFR, while 'security problems' and 'authentication, attestation and legal impediments' as important disadvantages of IFR. Ali Khan and Ismail (2009) found that 'global reach and mass communication', 'timeliness and updateability' and 'increased information and analysis' as important advantages of IFR, while 'security problems' and 'cost and expertise' as important disadvantages of IFR. Another study by Ali Khan and Ismail (2012, forthcoming) found that three main benefits to companies that engage in IFR are attracting foreign investors, promoting company to the public, and attracting local investors. The findings also revealed that three main benefits to the users who collect financial information of companies via their website are; increaseing timeliness and efficiency in obtaining financial information, helping users in the decision making process, and providing another medium of disclosure. The findings suggested three factors that are perceived as important by responding firms to engage in IFR which are; enhancing corporate image, company teller with the technology development, and competitors in the industry. The findings also revealed three factors that inhibit firms from engaging in IFR which are; the need to keep information updated to be of use, the required expertise from the company, and the concern over security of information.

The selected empirical studies addressing determinants of IFR have been discussed by Ali Khan and Ismail (2012). Several prior studies described IFR disclosure and presentation in specific countries or listed companies on specific stock exchanges. Ali Khan and Ismail (2012) provided the evidence that links several firm specific characteristics with the level of IFR disclosure. These include the size of the firm, which appears to be positively associated with the disclosure on the Internet. Also, evidence on other variables examined is largely inconclusive. Ali Khan and Ismail (2012) revealed that the trend of IFR researches starts from descriptive research, comparative research, association research, dimension and timeliness of IFR.

In summary, the wealth of recent research in this area also confirms the importance of the IFR issues. IFR is a new and wide research area (Moradi et al., 2011), important research agenda for future research (Ali Khan \& Ismail, 2011; Ali Khan \& Ismail, 2012), and has become an urgent investigation focusing on the international level (Al-Htaybat, 2011). However, perception studies on the benefits, factors, advantages and disadvantages of IFR are still lacking in emerging markets countries, especially Asian countries. In addition, to the best of our knowledge, limited studies have asked the interested parties and especially users about their perception and attitude in relation to IFR issues especially in emerging markets like Malaysia.

\section{Research Design}

The main purpose of this study is to investigate the perceptions of users of corporate annual report toward the benefits, factors, advantages and disadvantages of IFR. For this purpose, data were collected by a mean of survey questionnaire. In designing the questionnaire, comments and feedbacks from post graduate students and academics were elicited in an endeavour to ensure that questions were clear and precise. Based on their feedbacks, several modifications were made to the wording of some questions and some less important questions were deleted to reduce the length of the questionnaire. The target respondent of this study is a user of corporate annual report. Views from annual report users (share broker, remisier, business owner, graduates, academicians and 
other public users) are exposed to accounting information and have essential knowledge on how to use information contained in the annual report (Mohd Isa, 2006). Academics were chosen as a proxy group for corporate annual report users in this study because they were considered to be responsible for accounting education geared towards meeting the country's need for professional accountants (Mishekary \& Saudagaran, 2005). Students are believed to be corporate annual report users because of the nature of their academic specialization (Mohd Isa, 2006). Bank officer are the representative of a market economy (Mirshekary \& Saudagaran, 2005). Managers were also chosen as a proxy group for corporate annual report users in this study because they were considered to be responsible for making daily decisions affecting business process (Barsky \& Catanach, 2011). The respondents were asked to indicate their opinions on a fivepoint scale in terms of strongly disagree to strongly agree.

Each respondent received a marked questionnaire (for tracking purposes) together with a letter outlining the objective of the research, respondent confidentiality, and availability of survey result upon request, as well as a stamped addressed envelope. The researchers sent questionnaire to solicit their opinion on benefits, factors, advantages and disadvantages of IFR. In order to determine the importance of the item in IFR, a perception survey of four usergroups in Malaysia was conducted. The responses received from the questionnaire delivered are shown in Table 1. 268 questionnaires out of 390 one sent, were secured back with the respond rate of $68.72 \%$ percent, which is higher than the ample response rate (i.e. 15 to 20 percent) for a questionnaire survey (Standen, 1998). Frazer and Lawley (2000) claimed that the results of most studies using survey method obtained the response rate of $10 \%$ or lesser. The response rate is considered sufficient based on the fact that the response rate for survey method through post in Malaysia is around 10 to 16 percent (PricewaterhouseCoopers, 2002). This study respond rate is quite sufficient as compared with other previous studies which were 14 percent (Ku Ismail \& Chandler, 2005), 13.29 percent (Mohd Isa, 2006), 15.10 percent (Gibbins et al., 2007), 10.30 percent (Leng et al., 2007), and 15.11 percent (Ali Khan, 2010). Various efforts had been taken to improve the response rate including sending first and second reminders. The questionnaire consists of two parts. Part one relates to the general aspects, which are the background of the respondent such as gender, education level and major. Part two, consists of respondent perceptions toward benefits, factors, advantages and disadvantages of IFR.

Table 1: Distribution of Respondents According to Type of User

\begin{tabular}{|c|l|l|}
\hline No. & User Group & Respond \\
\hline 1 & Academic & 34 out of $50=68 \%$ \\
\hline 2 & Student & 74 out of $80=93 \%$ \\
\hline 3 & Manager & 106 out of $150=71 \%$ \\
\hline 4 & Bank officer & 54 out of $110=49 \%$ \\
\hline & Total & $\mathbf{2 6 8}$ Malaysian respondents \\
\hline
\end{tabular}




\section{Results}

From the data shown in Table 2, out of 268 respondents, 119 were males (44.4\%) and 149 were females respondents $(55.6 \%)$. In terms of academic qualification, 135 respondents are diploma holders (50.4\%), 76 respondents are degree or professional holders $(28.4 \%)$, nine respondents are $\mathrm{PhD}$ holders (3.4\%), while 48 respondents are master holders (17.9\%). In terms of academic specialization, 166 respondents majored in accounting (61.9\%), 33 respondents focused in the areas of finance (12.3\%), 20 respondents majored in accounting and finance (7.5\%), four respondents focused in investment, nine majored in economic (3.4\%) and 36 respondent majored in business administration (13.4\%). In terms of position in organization, 34 respondents work as academics (12.7\%), 74 respondents are student university (27.6\%), 106 respondents work as managers of the firm (39.6\%) and 54 respondents work as bank officers (20.1\%).

Table 2: Profile of Respondent (Users, $n=268$ )

\begin{tabular}{|l|l|c|c|}
\hline Demographic & Item & Frequency & Percentage (\%) \\
\hline Gender & Male & 119 & 44.4 \\
\cline { 2 - 4 } & Female & 149 & 55.6 \\
\hline Academic qualification & Diploma & 135 & 50.4 \\
\cline { 2 - 4 } & Degree / Professional & 76 & 28.4 \\
\cline { 2 - 4 } & Master & 48 & 17.9 \\
\cline { 2 - 4 } & PhD & 9 & 3.4 \\
\hline Majoring & Accounting & 166 & 61.9 \\
\cline { 2 - 4 } & Finance & 33 & 12.3 \\
\cline { 2 - 4 } & Accounting \& Finance & 20 & 7.5 \\
\cline { 2 - 4 } & Investment & 4 & 1.5 \\
\cline { 2 - 4 } & Economic & 9 & 3.4 \\
\cline { 2 - 4 } & Business Administration & 36 & 13.4 \\
\hline Position in organization & Academic Member & 34 & 12.7 \\
\cline { 2 - 4 } & University Student & 74 & 27.6 \\
\cline { 2 - 4 } & Manager & 106 & 39.6 \\
\cline { 2 - 4 } & Bank Officer & 54 & 20.1 \\
\hline
\end{tabular}

The following sections report the results of the users' perceptions toward the benefits of IFR to the company. The results of this examination reveal that respondents rated eight items as being great importance (with a mean of $4.05-4.27$ ), and one item as being of moderate importance (with mean of 3.92). The results in Table 3 show attracting foreign investors, promoting company wider to the public, providing wider coverage, attracting local investors, attracting potential customers, promotingtransparency, enhancing managerial efficiency, and discharging accountability as the eight main benefits of IFR to the company (mean > 4.00). 
Table 3: Benefits to the Company

\begin{tabular}{|c|c|c|c|c|}
\hline \multicolumn{2}{|c|}{ Item } & Mean & Std. Dev. & Rank \\
\hline \multicolumn{5}{|c|}{ Great importance } \\
\hline 1 & Attract foreign investors & 4.27 & .747 & 1 \\
\hline 2 & Promote company more wider to the public & 4.24 & .771 & 2 \\
\hline 3 & Provide wider coverage & 4.18 & .746 & 3 \\
\hline 4 & Attract local investors & 4.15 & .741 & 4 \\
\hline 5 & Attract potential customers & 4.13 & .783 & 5 \\
\hline 6 & Promote transparency & 4.07 & .806 & 6 \\
\hline 7 & Enhance managerial efficiency & 4.06 & .831 & 7 \\
\hline 8 & Discharge accountability & 4.05 & .796 & 8 \\
\hline \multicolumn{5}{|c|}{ Moderate importance } \\
\hline 9 & Improve financial performance & 3.92 & .860 & 9 \\
\hline
\end{tabular}

The results in Table 4 show increasing timeliness and efficiency in obtaining financial information, making investment decision process easier and faster, providing information for company inexpensively, providing accessibility to the users, helping users in the decision making process, and providing another medium of disclosure as the main benefits of IFR to the users (mean > 4.00). The results of this examination reveal that respondents rated six items as being of great importance (with a mean of 4.02 4.15).

Table 4: Benefits to Users

\begin{tabular}{|c|c|c|c|c|}
\hline \multicolumn{2}{|c|}{ Item } & Mean & Std. Dev. & Rank \\
\hline \multicolumn{5}{|c|}{ Great importance } \\
\hline 1 & $\begin{array}{l}\text { Increase timeliness and efficiency in obtaining financial } \\
\text { information }\end{array}$ & 4.15 & .800 & 1 \\
\hline 2 & Makes investment decision process easier and faster & 4.14 & .807 & 2 \\
\hline 3 & Provides information for company, inexpensively & 4.10 & .866 & 3 \\
\hline 4 & Provides accessibility to the users & 4.09 & .813 & 4 \\
\hline 5 & Helps users in the decision making process & 4.03 & .845 & 5 \\
\hline 6 & Provides another medium of disclosure & 4.02 & .729 & 6 \\
\hline
\end{tabular}

The following sections report the users' perceptions toward the factors that influenced them to adopt IFR. The results in Table 5 and Table 6 show enhancing corporate image, company teller with the technology development, and competitors in the industry as the three main factors that influence most influenced company to adopt IFR, while the required expertise from the company, and the need to keep information updated to be of use as the two main factors that most inhibited companies from adopting
IFR. The results of this examination reveal that respondents rated three items as being of great importance (with a mean of 4.09 4.20), and eight items as being of moderate importance (with mean of 3.44 - 3.90) for factors influences companies to practice IFR. Furthermore, the results of this examination reveal that respondents rated eleven items as being of moderate importance (with mean of 3.53 - 3.99) for factors influences companies not to practice IFR. 
Table 5: Factors Influences Companies to Practice IFR

\begin{tabular}{|c|c|c|c|c|}
\hline \multicolumn{2}{|c|}{ Item } & Mean & Std. Dev. & Rank \\
\hline \multicolumn{5}{|c|}{ Great importance } \\
\hline 1 & Enhance corporate image & 4.20 & .757 & 1 \\
\hline 2 & Company teller with the technology development & 4.16 & .823 & 2 \\
\hline 3 & Competitors in the industry & 4.09 & .795 & 3 \\
\hline \multicolumn{5}{|c|}{ Moderate importance } \\
\hline 4 & Obligations to community & 3.90 & .772 & 4 \\
\hline 5 & Receive government support & 3.87 & .840 & 5 \\
\hline 6 & Stability and improvement in share prices & 3.87 & .878 & 6 \\
\hline 7 & Directors desire to engage IFR & 3.82 & .827 & 7 \\
\hline 8 & Obtain funds from wider sources & 3.82 & .855 & 8 \\
\hline 9 & Media attention & 3.73 & .910 & 9 \\
\hline 10 & Pressures from stakeholders & 3.66 & .900 & 10 \\
\hline 11 & Win awards & 3.44 & .928 & 11 \\
\hline
\end{tabular}

Table 6: Factors Influences Companies Not to Practice IFR

\begin{tabular}{|c|l|c|c|c|}
\hline \multicolumn{2}{|l|}{ Item } & Mean & Std. Dev. & Rank \\
\hline \multicolumn{2}{|l|}{ Moderate importance } & & & \\
\hline 1 & Required expertise from the company & 3.99 & .805 & 1 \\
\hline 2 & Need to keep information updated to be of use & 3.99 & .897 & 2 \\
\hline 3 & Concern over security of information & 3.85 & .844 & 3 \\
\hline 4 & Concern over disclosure of proprietary information & 3.78 & .811 & 4 \\
\hline 5 & Too costly to setup and maintain & 3.75 & .950 & 5 \\
\hline 6 & There are alternative forms of obtaining information & 3.70 & .861 & 6 \\
\hline 7 & Potential legal liability & 3.69 & .889 & 7 \\
\hline 8 & Do not want to be too transparent & 3.69 & .981 & 8 \\
\hline 9 & Cost incurred outweigh benefits to company & 3.68 & .932 & 9 \\
\hline 10 & No legal requirement & 3.65 & .938 & 10 \\
\hline 11 & Fear of losing competitive advantage & 3.53 & .946 & 11 \\
\hline
\end{tabular}

A further analysis was carried out to investigate the perceptions of users toward the advantages and disadvantages of IFR. These items were extracted from the literature (Wallman, 1995; Green \& Spaul, 1997; Lymer \& Tallberg, 1997; Joshi \& AlModhahki, 2003; Ali Khan \& Ismail, 2008b; Ali Khan \& Ismail, 2009). The results in Table 7 show that respondents perceived increased information (downloadable) and analysis, global reach and mass communication, navigational ease, timeliness and updateability, and interaction and feedback as the five most important advantages of IFR (mean $>4.00$ ). On the other hand, Table 8 shows that respondents perceived security problems as the most important disadvantages of IFR (mean > 4.00). The results of this examination reveal that respondents rated five items as being of great importance (with a mean of 4.04 4.22 ), and two items as being of moderate importance (with mean of 3.94 - 3.95) for advantages of IFR. Furthermore, the results of this examination reveal that respondents rated one item as being of great importance (with a mean of 4.00), and five items as being of moderate importance (with mean of 3.69 3.96) for disadvantages of IFR. 
Table 7: Advantages of IFR

\begin{tabular}{|c|c|c|c|c|}
\hline \multicolumn{2}{|c|}{ Item } & Mean & $\begin{array}{l}\text { Std. } \\
\text { Dev. }\end{array}$ & Rank \\
\hline \multicolumn{5}{|c|}{ Great importance } \\
\hline 1 & Increased information (downloadable) and analysis & 4.22 & .707 & 1 \\
\hline 2 & Global reach and mass communication & 4.18 & .753 & 2 \\
\hline 3 & Navigational ease & 4.13 & .751 & 3 \\
\hline 4 & Timeliness and up-date ability & 4.08 & .755 & 4 \\
\hline 5 & Interaction and feedback & 4.04 & .785 & 5 \\
\hline \multicolumn{5}{|c|}{ Moderate importance } \\
\hline 6 & Presentation flexibility and visibility & 3.95 & .780 & 6 \\
\hline 7 & Cost beneficial & 3.94 & .812 & 7 \\
\hline
\end{tabular}

Table 8: Disadvantages of IFR

\begin{tabular}{|c|c|c|c|c|}
\hline \multicolumn{2}{|c|}{ Item } & Mean & $\begin{array}{l}\text { Std. } \\
\text { Dev. }\end{array}$ & Rank \\
\hline \multicolumn{5}{|c|}{ Great importance } \\
\hline 1 & Security problems & 4.00 & .855 & 1 \\
\hline \multicolumn{5}{|c|}{ Moderate importance } \\
\hline 2 & Cost and expertise & 3.96 & .815 & 2 \\
\hline 3 & Developed and developing country digital divide & 3.83 & .866 & 3 \\
\hline 4 & Poor website design and advertising & 3.73 & .871 & 4 \\
\hline 5 & Authentication, attestation and legal impediments & 3.72 & .856 & 5 \\
\hline 6 & Information overload & 3.69 & .943 & 6 \\
\hline
\end{tabular}

\section{Conclusion}

The main purpose of this study was to carry out an empirical evidence of the perceptions of corporate annual report users on the benefits, factors, advantages and disadvantages of IFR. Given that there is hardly any piece of empirical evidence on IFR practices in the emerging markets region, this paper is an important contribution to filling the gap in our knowledge of this subject. There are three important findings emerged from this study that can be used as a basis for future research. First, the respondents ranked that IFR implementation benefits the companies because it is able to attract foreign investors, promote company wider to the public, provide wider coverage, attract local investors, attract potential customers, promote transparency, enhance managerial efficiency, and discharge accountability compared to the traditional form of annual reports. Furthermore, IFR implementation benefits the users because IFR increases timeliness and efficiency in obtaining financial information, makes investment decision process easier and faster, provides information for company inexpensively, provides accessibility to the users, helps users in the decision making process, and provides another medium of disclosure. Second, the respondents ranked enhancing corporate image, company teller with the technology development, and competitors in the industry as the three most important factors that influence companies to adopt IFR. On the other hand, the required expertise from the company, and the need to keep information updated to be of use were ranked as the two main factors that most inhibited companies from adopting IFR. Third, respondents perceived increased information (downloadable) and analysis as the most important advantage of IFR, while security problems as the most important disadvantage of IFR. 
The current paper can be considered as one of the initial research papers in the area of IFR in Malaysia, and thus it provides some contribution. In a nutshell, this paper provides important insights into the benefits, factors, advantages and disadvantages of IFR from the perspectives of corporate annual report users which are neglected by prior research. However, there are several limitations to our study, and future research can refine and broaden our analysis in several aspects. The first is that some of the sample in user's group size is small. As the Internet continues to evolve, we expect more companies to create websites and adopt IFR within the next few years. Therefore, it would be interesting for researchers to further investigate this issue with a larger sample size. Second, the subject being surveyed can be described as a top management issue and it may be that not all respondents can reveal all the confidential information. Third, questionnaire may not be the best way for collecting data about IFR. Further research could try other approaches, such as interviewing companies, preparers and users. Fourth, this study only focuses on Malaysia. Future research may investigate and compare the issue between countries, especially between developed and developing countries. Finally, the Malaysian environment may be unique and, therefore, our findings may not be generalized in other emerging capital markets. Replications of IFR practice in other national settings warrant potential research extensions of this paper. Moreover, it is hoped that future research might be extended to improve on the limitations of this study, and hence add value to the research in this area of the various aspects of IFR.

These findings should assist corporate report users, preparers and regulators to understand the issues of IFR in emerging capital markets like Malaysia and to make necessary improvements. The current study may also contribute to the construction of new model and guideline of reporting functioning, which consist of both content and presentation dimensions. Furthermore, these findings would provide useful inputs for accounting policy makers or other regulatory bodies in the region to review existing disclosure requirements and corporate website policies. Within the limited knowledge of the researcher, this research is an early study upon the various aspects of IFR. It is hoped that the research findings will spark further studies related to IFR not only in Malaysia, but also in other countries, especially in finding empirical evidences. The researcher also hopes that the impact of this research will increase the knowledge of the community (e.g. those who prepare financial reports, the consumers, the proprietors, the industry experts, the legislators, the accounts legislators, the researchers and many other professional bodies) on the IFR issues. The results of this study may shed lights on the need for researching the impact of culture and attitudes of users of corporate annual report in Malaysia on their perceptions concerning various aspects of IFR. The results may also indicate that accounting associate bodies in Malaysia need to play a role in improving the awareness of the importance of IFR in making investment and business decisions. Finally, the findings of this study may also indicate that there is a need for more comprehensive studies to identify the similarities and differences in the perception of other users of corporate annual report such as investor in the emerging capital markets concerning the various aspects of IFR. That would help in the determination of the findings specific to Malaysia and in the formation of an overall view about the emerging capital markets countries.

\section{Acknowledgement}

The authors is very grateful for the financial support from Ministry of Higher Education (MOHE), Malaysia and Research Management Center (RMC), Universiti Teknologi Malaysia, Johor Bahru, Johor, Malaysia by Short Term Research Grant (New Academic Staff with $\mathrm{PhD}$ ) and Research University Grant. 


\section{References}

Abdelsalam, O. H., Bryant, S. M. \& Street, D. L. (2007). "An Examination of Comprehensiveness of Corporate Internet Reporting Provided by London-Listed Companies," Journal of International Accounting Research, 6(2), 1-33.

Abdelsalam, O. H. \& Street, D. L. (2007). "Corporate Governance and The Timeliness of Corporate Internet Reporting by U.K. Listed Companies," Journal of International Accounting, Auditing and Taxation, 16, 111130.

Al-Htaybat, K. (2011). "Corporate Online Reporting in 2010: A Case Study in Jordan," Journal of Financial Reporting \& Accounting, $9(1), 5-26$.

Ali Khan, M. N. A. (2010). "Pelaporan Kewangan Menerusi Internet: Indeks, Tahap Pelaporan dan Faktor Penentunya," Unpublished PhD Dissertation: Universiti Utara Malaysia, Sintok, Kedah.

Ali Khan, M. N. A. \& Ismail, N. A. (2008a). 'An Evolution of Internet Financial Reporting Research,' Paper presented at International Accounting and Business Conference (IABC) 2008, Puteri Pan Pacific, Johor Bahru, Johor, August 18-19.

Ali Khan, M. N. A. \& Ismail, N.A. (2008b). 'Faktor, Kelebihan dan Kekurangan Pelaporan Kewangan Menerusi Internet: Satu Kajian Awal,' Paper presented at National Management Conference (NaMac) 2008, Primula Beach Resort, Kuala Terengganu, Terengganu, December 13-14.

Ali Khan, M. N. A. \& Ismail, N. A. (2009). 'Internet Financial Reporting in Malaysia, Factors, Pros and Cons,' Accountants Today, 22(2), 28-31.

Ali Khan, M. N. A. \& Ismail, N. A. (2011). "The Use of Disclosure Indices in Internet Financial Reporting Research," Journal of
Global Business and Economics, 3(1), 157173.

Ali Khan, M. N. A., \& Ismail, N. A. (2012). 'A Review of E-Financial Reporting Research,' Journal of Internet and e-Business Studies, 2012, 16 pages.

Ali Khan, M. N. A., \& Ismail, N. A. (2012). 'Internet Financial Reporting by Malaysian Preparers,' Terengganu International Finance and Economics Journal, forthcoming.

Allam, A. \& Lymer, A. (2003). "Development in Internet Financial Reporting: Review and Analysis Across Five Developed Countries," The International Journal of Digital Accounting Research, 3(6), 165-199.

Al-Moghaiwli, M. H. (2009). "A Survey of Internet Financial Reporting in Qatar," Journal of Economic \& Administrative. 25(1), 1-20.

Aly, D., Simon, J., \& Hussainey, K. (2010). "Determinants of Corporate Internet Reporting: Evidence from Egypt," Managerial Auditing Journal, 25(2), 182-202.

Ashbaugh, H., Johnstone, K. M. \& Warfield, T. D. (1999). "Corporate Reporting on the Internet," Accounting Horizons, 13(3), 241257.

Barsky, N. P., \& Catanach, A. H. (2011). "Every Manager Can Be an Innovator," Strategic Finance, 93(2), 22-29.

Bonson, E. \& Escobar, T. (2002). "A Survey on Voluntary Disclosure on the Internet: Empirical Evidence from 300 European Union Companies," The International Journal of Digital Accounting Research, 2(1), 27-51.

Bonsón-Ponte, E., Escobar-Rodríguez, T. \& Flores-Muñoz, F. (2006). "Online Transparency of Banking Sector," Online Information Review, 30(6), 714-730. 
Boubaker, S., Lakhal, F., \& Nekhili, M. (2012). "The Determinants of Web-Based Corporate Reporting in France," Managerial Auditing Journal, 27(2), 126-155.

Brennan, N. \& Hourigan, D. (1998). 'Corporate Reporting on the Internet by Irish Companies,' Accountancy Ireland, 30(6), 1821.

Chan, W. K. \& Wickramasinghe, N. (2006). "Using the Internet for Financial Disclosure: The Australian Experience," International Journal Electronic Finance, 2(1), 118-150.

Craven, B. M. \& Marston, C. L. (1999). "Financial Reporting on the Internet by Leading UK Companies," The European Accounting Review, 8(2), 321-333.

Davey, H. \& Homkajohn, K. (2004). "Corporate Internet Reporting: An Asian Example," Problems and Perspectives in Management, 2, 211-227.

Debreceny, R., Gray, G. L. \& Rahman, A. (2002). "The Determinants of Internet Financial Reporting," Journal of Accounting and Public Policy, 21(4-5), 371-394.

Deller, D., Stubenrath, M. \& Weber, C. (1999). "A Survey on the Use of the Internet for Investor Relations in the USA, the UK and Germany," The European Accounting Review, $8(2), 351-364$.

Desoky, A. M. (2009). "Company Characteristics as Determinants of Internet Financial Reporting in Emerging Markets: The Case of Egypt," Accounting in Emerging Economies, 9, 31-71.

Ettredge, M., Richardson, V. J. \& Scholz, S. (2001). "The Presentation of Financial Information at Corporate Web Sites," International Journal of Accounting Information Systems, 2, 149-168.

Ettredge, M., Richardson, V. J. \& Scholz, S. (2002). "Dissemination of Information for
Investors at Corporate Web Sites," Journal of Accounting and Public Policy, 21, 357-369.

FASB. (2000). 'Business Reporting Research Project: Electronic Distribution of Business Reporting Information,' Steering Committee Report Series, Financial Accounting Standards Board.

FASB. (2001). 'Improving Business Reporting: Insights into Enhancing Voluntary Disclosures,' Financial Accounting Standards Board.

Fisher, R., Oyelere, P. \& Laswad, F. (2004). "Corporate Reporting on the Internet Audit Issues and Content Analysis of Practices," Managerial Auditing Journal, 19(3), 412-439.

Frazer, L., \& Lawley, M. (2000). 'Questionnaire Design \& Administration,' Australia: John Wiley \& Sons.

Garg, M. C. \& Verma, D. (2010). "Web-Based Corporate Reporting Practices in India," The IUP Journal of Accounting Research \& Audit Practices, IX(3), 7-19.

Gibbins, M., McCracken, S. A., \& Salterio, S. E. (2007). "The Chief Financial Officer's Perspective on Auditor-Client Negotiations," Contemporary Accounting Research, 24(2), 387-422.

Green, G. \& Spaul, B. (1997). 'Digital Accountability,' Accountancy, International Edition, 49-50, May.

Haniffa, M. H. \& Ab. Rashid, H. (2004). 'The Determinants of Voluntary Disclosures in Malaysia: The Case of Internet Financial Reporting,' Paper presented at International Business Management Conference 2004, Kuantan, Pahang, December 6-7.

Hassan, S., Jaaffar, N., Johl, S. K. \& Mat Zain, M. N. (1999). 'Financial reporting on the internet by Malaysian companies: Perceptions and Practices,' Asia-Pacific Journal of Accounting, 6(2), 299-319. 
Henchiri, J. E. (2011). "Voluntary Web-Based Disclosures by Moroccan and Tunisian Companies," EuroMed Journal of Business, 6(2), 155-173.

Hindi, N. M. \& Rich, J. (2010). "Financial Reporting on the Internet: Evidence from the Fortune 100," Management Accounting Quarterly, 11(2), 11-21.

Jones, M. J. \& Xiao, J. Z. (2004). "Financial Reporting on the Internet by 2010: A Consensus View," Accounting Forum, 28(3), 237-263.

Joshi, P. L. \& Al-Modhahki, J. (2003). "Financial Reporting on the Internet: Empirical Evidence From Bahrain and Kuwait," Asia-Pacific Journal of Accounting, 11(1), 88-101.

Kelton, A. S. \& Yang, Y.- W. (2008). "The Impact of Corporate Governance on Internet Financial Reporting," Journal of Accounting and Public Policy, 27(1), 62-87.

Ku Ismail, K. N. I., \& Chandler, R. (2005). "Perceptions of Professional Investors in Malaysia on the Usefulness of Quarterly Financial Reports," Jurnal Pengurusan, 24, 105-124.

Leng, T. L., Lazar, J., \& Othman, R. (2007). "Adoption of Financial Reporting Standards (FRSs): Impact on Malaysian Companies," Unpublished research report. Malaysian Accountancy Research and Education Foundation.

Liu, L. G. (2000). "The Emergence of Business Information Resources and Services on the Internet and its Impact on Business Librarianship," Online Information Review, 24(3), 234-255.

Lybaert, N. (2002). “On-Line Financial Reporting: An Analysis of the Dutch Listed Firms," The International Journal of Digital Accounting Research, 2(4), 195-234.
Lymer, A. (1997). 'The Use of the Internet in Company Reporting: A Survey and Commentary on the Use WWW in Corporate Reporting in UK,' Paper presented at the British Accounting Association Annual Conference, Birmingham.

Lymer, A. (1999). "The Internet and the Future of Corporate Reporting in Europe," European Accounting Review, 2(2), 289-301.

Lymer, A., Debreceny, R., Gray, G. L. \& Rahman, A. (1999). "Business Reporting on the Internet," IASC Research Report.

Lymer, A. \& Tallberg, A. (1997). "Corporate Reporting and the Internet - A Survey and Commentary on the Use of the WWW in Corporate Reporting in the UK and Finland," Paper presented at the Annual Congress of the European Accounting Congress, Graz, Austria, April.

Marston, C. (2003). "Financial Reporting on the Internet by Leading Japanese Companies," Corporate Communication: An International Journal, 8(1), 23-34.

Marston, C. \& Leow, C. Y. (1998). 'Financial Reporting on the Internet by Leading UK Companies,' Paper presented at the 21st Annual Congress of the European Accounting Association, Antwerp, Belgium.

Marston, C. \& Polei, A. (2004). “Corporate Reporting on the Internet by German Companies," International Journal of Accounting Information System, 5, 285-311.

McDonald, R. \& Lont, D. (2001). "Financial Reporting on the Web - A 2001 Review," Chartered Accountants Journal, 64-68.

Misrshekary, S. \& Saudagaran, S. M., (2005). "Perceptions and Characteristics of Financial Statements Users in Developing Countries: Evidence from Iran," Journal of International Accounting, Auditing and Taxation, 14, 33-54. 
Mohd Isa, R. (2006). 'Graphical Information in Corporate Annual Report: A Survey of Users and Preparers Perception,' Journal of Financial Reporting \& Accounting, 4(1), 3960.

Moradi, M., Salehi, M. \& Arianpoor, A. (2011). "A Study of the Reasons for Shortcomings in Establishment of Internet Financial Reporting in Iran," African Journal of Business Management, 5(8), 3312-3321.

Nurunnabi, M., \& Hossain, M. A. (2012). “The Voluntary Disclosure of Internet Financial Reporting (IFR) in an Emerging Economy: A Case of Digital Bangladesh," Journal of Asian Business Studies, 6(1), 17-42.

Oyelere, P., Laswad, F. \& Fisher, R. (2003). "Determinants of Internet Financial Reporting by New Zealand Companies," Journal of International Financial Management and Accounting, 14(1), 26-61.

Pervan, I. (2006). "Voluntary Financial Reporting on the Internet- Analysis of the Practice of Stock-Market listed Croatian and Slovene Joint Stock Companies," Financial Theory and Practice, 30(1), 1-27.

Pervan, I. \& Sabljic, M. (2011). "Voluntary Internet Financial Reporting in Croatia Analysis of Trends and Influential Factors," The Business Review, 17(2), 213-219.

Petravick, S. \& Gillett, J. (1996). "Financial Reporting on the World Wide Web," Management Accounting, 26-29, July.

PricewaterhouseCoopers. (2002). 'Market Readiness for Disclosure-Based Regulation, Highlights from the Survey on the Readiness of the Malaysian Capital Market Participants for DBR,' Kuala Lumpur: Securities Commission.

Pirchegger, B. \& Wagenhofer, A. (1999). "Financial Information on the Internet: A Survey of the Homepages of Austrian Companies," The European Accounting Review, 8(2), 383-395.
Sanchez, I.- M. G., Dominguez, L. R. \& Alvarez, I. G. (2011). "Corporate Governance and Strategic Information on the Internet," Accounting, Auditing \& Accountability Journal, 24(4), 471-501.

Spaul, B. (1997). "Corporate Dialogue in the Digital Age," London. The Institute of Chartered Accountants in England and Wales.

Trites, G. (1999). 'The Impact of Technology on Financial and Business Reporting,' Canadian Institute of Chartered Accountants.

Van Standen, C. J. (1998). "The Usefulness of the Value Added Statement in South Africa," Managerial Finance, 24(11), 44-59.

Wallman, S. (1995). 'The Future of Accounting and Disclosure in Evolving World: The Need for Dramatic Change,' Accounting Horizon, 9(3), 81-91.

Xiao, J. Z., Jones, M. J. \& Lymer, A. (2005). “A Conceptual Framework for Investigating the Impact of the Internet on Corporate Financial Reporting," The International Journal of Digital Accounting Research, 5(10), 131-169.

Xiao, J. Z., Yang, H. \& Chow, C. W. (2004). “The Determinants and Characteristics of Voluntary Internet-Based Disclosures by Listed Chinese Companies," Journal of Accounting and Public Policy, 23, 191-225. 